\title{
VOCALIZATION IN THE WHITE PELICAN
}

\section{by Martin McNicholl, Zoology Department, University of Manitoba*}

A. C. Bent (1922) called the White Pelican (Pelecanus erythrorhynchos) "particularly silent birds." Neither Roger Tory Peterson (1947) nor Robbins, Bruun, and Zim (1966) make any mention of voice for the White Pelican in their popular field guides. Elsewhere, Peterson (1961) calls the adults "virtually silent." Skinner (1917) stated that "the old pelicans never make a sound." Bent (op. cit.) cites Dr. P. L. Hatch, writing in 1892 , as saying they make a loud, difficultto-describe call from great heights in the sky. However, neither Bent (op. cit.) nor Palmer (1962) could find any other references to cails from adults away from the breeding colony.

It would appear from the above that adult pelicans are normally silent birds, at least away from the breeding grounds. I was therefore surprised on May 17, 1967 to hear a low grunt from at least one of two pelicans which flew overhead, just above tree level, as I stood on the well-treed ridge along the south shore of Lake Manitoba at the University of Manitoba Field Station at Delta, Manitoba. Although pelicans frequently fish along Lake Manitoba, the nearest known breeding colony to Delta is at East Shoal Lake (Lies and Behle, 1966; Anderson and Bartonek, 1967), approximately 36 miles distant.

The sound I heard was not a loud call like that described by Hatch, and was not made at a high altitude. It was more like the "grunt" call described in the literature for the adults on the breeding grounds (and also heard by Dr. Roger M. Evans and myself at a colony on Dog Lake, Manitoba on June 11, 1967). These calls have been described by Bent (1922) as "low-toned grunts" or "subdued croaking." He cites Chapman as calling this "a deep voiced, not loud,

*Publication No. 6 of the University of Manitoba Field Station, Delta. murmuring groan", Grinnell as referring to it as "a grunting quack", and Audubon as likening it to a sound "produced by blowing through the bunghole of a cask." Peterson (1961) calls it a "low groan." Schaller (1964) found these "murmuring grunts" to be quite common at the colony. $\mathrm{He}$ also heard "loud nasal ho-ho-hos" and grunts during displays of nest relief ceremonies, and "loud harsh grunts" during copulation between adults and attempted copulations of young by adults. It may be noted that Bent (op. cit.) says the grunt call is "not audible at great distance." As the pelican often "soars at great heights" (Robbins et al., op. cit.), they may call more than is generally supposed away from the breeding colony, but their calls may not be heard by the human observer below.

In contrast to the adults, young pelicans are quite vocal. Skinner (1917) says they have "only a low grunt", but Bent (op. cit.) cites Dr. Chapman as saying they make "a low coughing whining grunt", which in a chorus "creates quite a volume of sound." Schaller (op. cit.) notes that young at hatching and one week old emit a "harsh kek-kek", but at about two weeks this becomes a "nasal waa-o, waa-o." In captivity the young have been known to give "low hoarse prologned sqawks" for "a few davs" after capture (pers. comm. C. McGrati, fide V. Scott). That the young are strongly vocal at an early age was strikingly demonstrated on our visit to Dog Lake, where vocalizations similar to that described by Schaller (1964) for newly-hatched pelicans were heard emanating from pipped eggis.

I would like to thank Carol McGrath and Vere Scott for information on pelicans in zoos, and Dr. R. M. Evans and Dr. R. W. Nero for critically reading this note. My work at the field station was supported by a 
National Research Council of Canada grant.

\section{LITERATURE CITED}

Anderson, D. W. and J. C. Bartonek. 1967. Additional observations on the status of North American White Pelicans. Condor $69: 311-313$.

Bent, A. C. 1922 (Dover edition, 1964). Life histories of North American petrels and pelicans and their allies. U.S. Nat. Mus. Bull. 121. xiv plus $335 \mathrm{pp}$.

Lies, M. F., and W. H. Behle. 1966. Status of the White Pelican in the United States and Canada through 1964. Condor 68:279-292.

Palmer, R. S. (ed.) 1962. Handbook of North American birds. Vol. I. Loons through flamingos. 567 pp. Yale University Press, New Haven and London.

Peterson, R. T. 1947. A field guide to the birds (2nd revised edition). Houghton Mifflin Co., Boston. xxiv plus $290 \mathrm{pp}$.

Peterson, R. T. 1961. A field guide to western birds (2nd edition). Houghton Mifflin Co., Boston, xxvi plus $366 \mathrm{pp}$.

Robbins, C. S., B. Brunn and H. S. Zim. 1966. Birds of North America. Golden Press, New York. $340 \mathrm{pp}$.

Schaller, G. B. 1964. Breeding behavior of the White Pelican at Yellowstone Lake, Wyoming. Condor $63: 3-23$.

Skinner, M. P. 1917. The birds of Molly Island, Yellowstone National Park. Condor 19:177182.

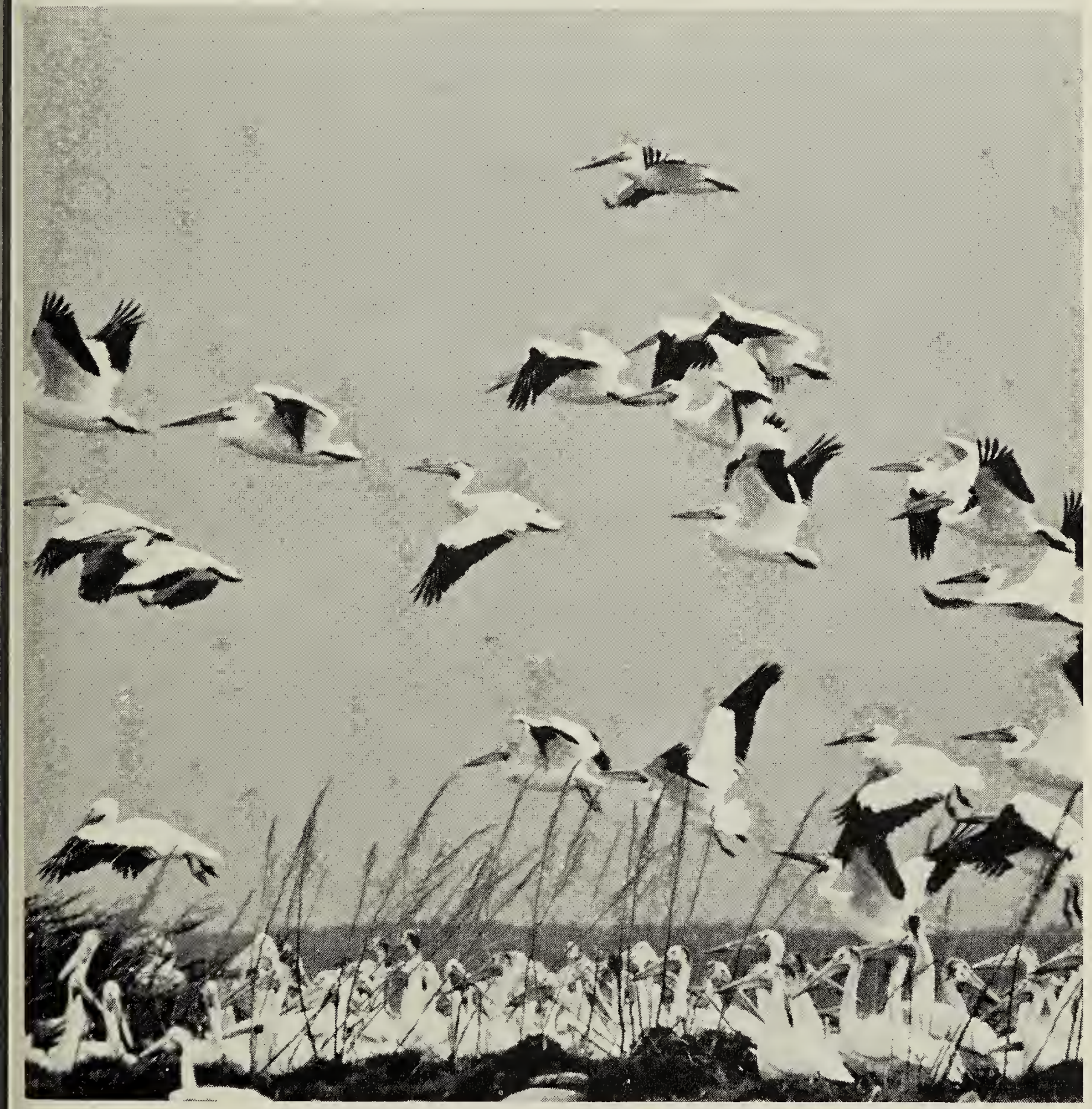

White Pelicans

Photo by Harold Hosford, Winnipeg 